\title{
Study of Architectural Graduate Education Based on Changes in the Thinking and Organizing of Graduate Programs
}

\author{
Yan-song WANG ${ }^{1}$, Shu-yu $\mathrm{XIAO}^{1, *}$ and Fan $\mathrm{BAO}^{2}$ \\ ${ }^{1}$ Wuhan University, Wuhan, Hubei, China \\ ${ }^{2}$ Guizhou Normal University, Guiyang, Guizhou, China \\ ${ }^{*}$ Corresponding author
}

Keywords: M.Arch; Educational Research; Curriculum; Teaching Reflection.

\begin{abstract}
This essay is based on the author's long time teaching practice in architectural graduate education, and aims to look through some obvious problems in today's architectural graduate programs in university. For these problems, the essay offers some thinking about the aspects of education, such as the impact of changes from undergraduate programs to graduate, students' abilities in research and practice, and also some constructive criticism about the courses and programs of architectural graduate education.
\end{abstract}

\section{Introduction}

China's modern architectural education started in 1930s, and after many years of turmoil, took is form in 1950s. It was built by pioneers of architect educators such as Liang Sicheng, Liu Dunzhen, Yang Tingbao, Tong Jun, Feng Jizhong, etc. [1] with their knowledge and experiences they received abroad, and was developed into today's architectural education system. China's graduate education started with her university educational system set up in her early days. It has gone through phases like the beginning (1949-1966), the stagnation (1966-1977), the re-built (1981-1985), the reforming (1986-1991), the evolving (1992-1998), and the developing (1999-) [2]. After the Chinese economic reform, her university education has been thriving, and benefits generations of accomplished young people. As a result, Chinese architects, design and construction enterprises have filled this land with their non-stop works, and amaze the world.

However, in recent years of the developing of architectural education, there have been some apparent shortcomings. Graduate education is undoubtedly the corner stone of university education. And there has been a 2\% increase in the numbers of graduate students in the past 15 years. So the problems in our graduate education process are ever more noticeable considering the number of people involved.

This essay is based on the author's teaching, research and professional practices through the years, and its aim is to study the changes needed in the thinking and organizing of graduate programs for both the architecture students and schools.

\section{Changes of Students' Roles}

\subsection{From High School to Undergraduate}

To study architectural graduate education, we need to look from the first change when students come to university from high school. For Chinese student, architectural education is a novelty and no easy task. For one thing, architectural education requires abilities such as sensation of space, artistic imagination, aesthetics, creativity, observation from daily life, logical thinking, which is quite a demanding subject. For another thing, it's even more demanding a job to keep up the spirit and passion in those five long years of study. The architecture design studio as the foundation of architectural education, which is set to gradually help students to master the requested skills and abilities in this profession, turns out to be a battlefield where students are fighting with all their means to challenge the mission impossible. They all want to be the best, or the "starchitect", and stop at nothing until their drawings impress the judges. This constant competition is a good way to 
motivate young people, but it weighs too much in the undergraduate programs that it could easily bring failure and also hurt students while leaving them defeated without actually knowing how. Even worse, after all in their minds some students would feel they are just ungifted, and lose their passion.

From high school to university, promising students are giving away some abilities or the chances to get improved without notice. Such extra abilities such as language, writing, science, logic, though basic or even irrelevant as they may seem, are the essential elements in architectural graduate education. So the highly specialization in undergraduate programs does help the students to acquire professionalism in some way, but in another way it also halts their further self-development and leads them to a dead end. The problem is obvious when students come to graduate from undergraduate, especially when doing researches.

\subsection{From Undergraduate to Graduate}

The second change is from undergraduate to graduate. Should graduate education follow its previous course? Should graduate students continue to weave new stories and chase after mystic inspirations for their design? Today architectural academic research is ever more professional and specific, which requires more academic abilities and qualities from students in their study. As for academic research, it's harder for architectural student than those in other fields because of the huge differences between undergraduate and graduate education in terms of study and methods. The differences are about thinking, or we can put it, come to your senses, or going back to normal. Students should be aware, that once they choose graduate education, they are not to be in the spotlight to impress the world, but to step down and see architecture as solemn subject, and to gain those basic academic qualities and abilities. The fear is that students still don't get the reason to pursue graduate education after the rigid and narrow minded undergraduate programs, not to speak about those who only put eyes on diploma without a genuine heart for study.

Let's take another look at the problems of the myth of making starchitet, we can see that it is hard to pursue an architecture career; it could lead to a happy ending, and possibly a sad one. It is a challenge for students to get a happy ending as well as for architecture schools. Architectural graduate study is an experimental process, during which students are not required to do any exact researches, but to work with some elementary academic methods. But the problem is, it is natural that architectural undergraduate programs focus more on sensitive experiences, but should graduate programs follow the same old way to make students even more narcissistic than before? China's architecture schools have often brought realistic design projects and practices into their graduate education system. But in many cases, the students involved are either tired workers or the ones that got away. Most graduate students are lack of passion, ability knowledge or patience in design practice. Tutors could find a huge difference between them and those young people working in design institutes and companies who are more dedicate, practical and authentic.

Actually, design and research are two different things. Students should be aware of that, or they couldn't do either of them in graduate study. Mr. Liang Sicheng had stated that architect should be also a scientist, an engineer, a philosopher, a poet, which is quite a romantic idea. But in reality, these roles are too much for an architecture student. In a small way, architecture design is more about imaginative thinking, without which it is mere making drawings like a machine. But scientific research needs hard and tedious work. From my teaching experience, students who are talented in design may not try to do research, but to excel in design --for the same reason of $\mathrm{Mr}$. Chen Danqing's criticism on doctor of fine arts. Also, there has been hardly any success in more design studios in architectural graduate programs.

Why graduate education? Except for diploma, a main attraction is the advanced academic development of the school. Students would be willing to follow those well-established teachers, get involved in their works and researches, and find themselves a role model. But in many schools, architecture department lacks resources or guidance. As a result, their graduate education often lacks initiative or success. We should not just blame the students or the schools; we are still trying 
to find the right way for architecture education after all these years. We couldn't properly define architecture research and practice yet, and students could be the victims of a system in which the goals and methods are not clear. For some schools, it's a problem of experience, but for this subject, it is a question for all.

\section{Some Doubts about Graduate Education}

In my long time teaching practice, I've often come to students with some doubts about the purpose of graduate education. Not sure what they would gain from it, these young people became bewildered, filled with regrets. This is not a new phenomenon; it comes from the problems of the education system.

Firstly, architectural undergraduate education underestimates the value of scientific research and discovery, especially when it relies too much on artistry and inspiration. In 5-years study, students are enjoying themselves in find their inspiration and dreaming to become a starchitect someday. This is not a bad thing because a professional architect does need his passion and creativity. But as we have seen, the study of design relying on inspiration and experience doesn't reach further than other social subjects. Anyway, architecture design is not pure art, unrealistic imagination doesn't help here, and passion could easily fade away. Many architects without a graduate degree would like to go back to school and do some study to bring their design to the next level. This is a desirable thought, but it's also a false statement. To study more and communicate with more people is how we become a better self, but it has nothing to do with a graduate degree. It's a misunderstanding that school could give you fresh mind and motivation.

Secondly, what's so special about architectural graduate programs in terms of improvement of design? This is a question for other subjects too. We have pretty much the same things as in undergraduate programs, lectures of poor quality, self-exile, uncertain future and the shortcomings of the education system. Graduate education costs young students a great deal of time and energy, but undermines their faith in study and discovery.

Thirdly, even we couldn't get too much from 3-years of graduate education, we have to make some points clear: one, graduate education should be different from undergraduate, in programs and methods. Two, graduate education should fix the lack of logistic thinking in undergraduate education, not just add another 3 years of study relying on sensitive experience.

\section{What Graduate Programs could Offer?}

Based on my thoughts about architectural graduate education, as for what graduate programs could offer the students, here I come up with four aspects.

1) Vision. Learn about more things, make more friends, learn from more teachers, read, listen and share more, find your passion, or at least make a good use of the school's resource for your academic research.

2) Responsibility. Participate in researches and projects, be responsible for your job and your team, and do your thing. You are not trained to earn trust from your teachers, fellow students and clients in undergraduate programs, but you are now. This is an important change from undergraduate to graduate. With this experience, you can assure people that you are capable of dealing with your own job in the future.

3) Method. Now that you are a graduate student, you need to be armed with logistic thinking and systematic research methods, rather than those superficial concepts like before. You are to learn basic methods in qualitative and quantitative researches. Find a question, then analyze it, and solve it if you could. In the process, collect materials, sort them out, make comparison and draw conclusion, as well as learn from others' new ideas and methods.

4) Experience. Simply put, graduate education is an experience. Whether it's a joy or trouble, it's your own experience, and experience is a fortune. You can't always run away from trouble, whether 
it is about your relationships with others, or your projects, clients, essays. Troubles could turn out to be chances if you face them bravely. And each time you run, you'd lose your chance and invaluable experience, and worse, you'd become unreliable and inefficient.

\section{Problems in Graduate Programs}

Generally, Master of Architecture programs include three research areas, architectural design and theory, Architectural History and Theory, Building Technology Science. As we have learned in this essay, there are many problems in graduate programs as well as undergraduate programs. In terms of teaching, here are some facts that we should be aware of.

The programs last too long. The master's program in architecture-- academic or professional-usually lasts 2-3 years. From students' point of view, one year for courses, one year for research and practice, one year for thesis and job hunting. Actually the time span could be shortened to 2 even 1 year, especially for professional mater program which focus more on practice. There's no need to study in the classroom, and let research, practice and job wait until next year. This is just wishful thinking.

2) The courses are no different with those in undergraduate programs. It's a bad idea to make graduate students have another year of lectures. They would sit in the classroom for another year and find that there's nothing new to what they already have in the previous 5 years. If we call it an improvement, how can we prove it? I'm not trying to underestimate the study, but the program is an embarrassment. For students, except for some coursed focused on methods, most of the others are the same version of undergraduate program, or a poorer version. The disappointment in the first year of graduate program is quite harmful when it could kill students' passion.

3) The courses are of low-quality. The courses in graduate program include a lot of presentations by students, which seem like a new way of study, but the quality is poor. Several groups read their PPT filled with materials downloaded from internet, and the class is over. This is useless for research or practice.

4) The program overlooks individuality. The program doesn't offer much choice but give the same courses to around 20-30 students, who can't find a program tailored according to their own needs and interest. We do have 3 research areas in architectural graduate education; it's hard to understand why courses for these different areas are pretty much the same.

5) The courses are examined without care. At the end of a course, a design project or a thesis is also required. But it's very hard to make sure that each student's work is examined or improved carefully by the director of that course.

\section{Advice for Graduate Programs}

Based on the study of the situation of architectural graduate program, considering its preference towards practice while being short of scientific methods and logistic thinking, I'd like to share some advices:

1) Set up studios. Among the 8 course in the first year of graduate program, a student should choose one course directed by his tutor, one course focused on the theory and research methods in his chosen research area, while the other 6 courses directed by teachers' studios.

2) Include research and design projects. Meanwhile, some of the other 6 courses should be directed by teachers who are in charge of his research or practice projects, and the program should be in a small scale around 10 people. Graduate student should participate in their elective courses and the assignments given by the studios. Teachers carrying no project shouldn't direct course.

3 ) Include subjects from other departments and schools. One course among those 6 should be directed by other department of the schools, one by other school in the university.

4) Allow alternative credits. In their first year, students should be encouraged to enter design 
competitions and publish essays. If one could win a regional competition, or publish in core journals, then accordingly he's given the credits for one course.

\section{Summary}

The problems in architectural education in universities have been more or less a pain for teachers and students, even companies, and the whole industry. Of course the reform of university education system needs to be delicate, but if nothing is to be done, those problems would hurt us and our society even more. So we'd better see them through now rather than ignoring and regretting before it's too late. If our education system fails to meet the needs of society, we all should feel sorry and responsible for the architecture industry. The development of a graduate student needs the combined efforts from students, teacher and schools. We all need to give it a second thought, about what graduate students should get from their education--abilities, qualities, skills, and even moralities, as well as what courses and programs are proper for their needs. We teachers are responsible for each young architecture graduate student, so that they can make the most of their days and eventually do their jobs, and we could do ours.

\section{References}

[1] Zhang Caili. Reflectionon Architectural Education current situation in China [J]. Duyuxie, 2015, (1): 55-56.

[2] Zhang JinWei. Study on Characteristics of Postgraduate Education System from 1949 to 1984 [D]. ZheJiang Normal University, 2015.

[3] Qian Feng. Modern Ideal in Collegiate Education of Architecture in China (1920s-1980s) [D]. Tongji University, 2006.

[4] Tian Yong. Reseach on the Training Mode of Architectural Education in China Based on Effective Goal [D]. Tianjin University, 2014. 